\title{
Lipopolysaccharide derived from the digestive tract provokes oxidative stress in the liver of dairy cows fed a high-grain diet
}

\author{
J. A. Abaker, T. L. Xu, D. Jin, G. J. Chang, K. Zhang, and X. Z. Shen ${ }^{1}$ \\ College of Veterinary Medicine, Nanjing Agricultural University, Nanjing 210095, P.R. China
}

\begin{abstract}
The aims of this study were to measure oxidative stress parameters and to investigate the molecular mechanism triggered by grain-induced subacute ruminal acidosis in mid-lactation cows. Twelve HolsteinFriesian cows with an average weight of $455 \pm 28 \mathrm{~kg}$ were divided into 2 groups and subjected to 2 diets over 18 wk: either a low-grain (forage-to-concentrate ratio $=$ $6: 4$ ) or a high-grain (forage-to-concentrate ratio $=4: 6$ ) diet based on dry matter. Being fed a long-term highgrain diet resulted in a significant decrease in rumen $\mathrm{pH}$ and a significant increase in ruminal lipopolysaccharide (LPS) at $4 \mathrm{~h}$ postfeeding in the morning. The increase was also observed in LPS concentrations in the portal vein, hepatic vein, and jugular vein blood plasma as well as reduced milk yield in a high-grain diet. Cows fed a high-grain diet had lower levels of catalase and glutathione peroxidase (GPx) activity and total antioxidant capacity than cows fed a low-grain diet; however, super oxide dismutase (SOD) activity and malondialdehyde (MDA) levels were higher in both the liver and the plasma of high-grain than in low-grain cows. Positive correlations were observed between plasma LPS versus hepatic MDA, plasma MDA, and hepatic SOD activity, whereas hepatic GPx and plasma GPx were negatively correlated with plasma LPS. The relative mRNA abundances of GPX1 and CAT were significantly lower in the liver of cows fed a high-grain diet than those fed a low-grain diet, whereas SOD1 was significantly higher in cows fed a high-grain diet than cows fed a low-grain diet. The expression levels of Nrf2, NQO1, MT1E, UGT1A1, MGST3, and MT1A were downregulated, whereas $N F-k B$ was upregulated, in cows fed a high-grain diet. Furthermore, nuclear factor E2-related factor 2 (Nrf2) total protein and mRNA levels were significantly lower than in low-grains. Our results demonstrate the relationship between the translocated LPS and the suppression of cellular antioxidant defense
\end{abstract}

Received January 8, 2016.

Accepted July 20, 2016.

${ }^{1}$ Corresponding author: xzshen@njau.edu.cn capacity, which lead to increased oxidative stress and suggests that the Nrf2-dependent antioxidant response may be affected by higher levels of LPS translocated to the bloodstream.

Key words: lipopolysaccharide, oxidative stress, liver, high-grain diet

\section{INTRODUCTION}

Subacute ruminal acidosis is a common health problem in many dairy herds (Kleen et al., 2003). Dairy farmers largely use a high-grain diet to meet the high energy requirements associated with periods of high milk production. Increasing the grain-to-fiber ratio leads to a depression of ruminal $\mathrm{pH}$ between 5.2 to 5.8 per day for several hours, which is defined as SARA (Gozho et al., 2005; Steele et al., 2011). This reduction in $\mathrm{pH}$ disturbs the balance of the microbial environment in the rumen and leads to a massive release of bacterial endotoxin (LPS) from gram-negative bacteria in the rumen (Emmanuel et al., 2008). Lipopolysaccharide can be translocated into the blood due to possible changes in permeability and injury to the epithelial tissue of the digestive tract (Jiang et al., 1995; Gozho et al., 2005; Khafipour et al., 2009). Because LPS is major component of the outer membrane of gram-negative bacteria and a chief member of the pathogen-associated molecular patterns, the immune system detects the translocated LPS (Kallapura et al., 2014). The LPS is believed to be largely responsible for most of the described toxic inflammatory reactions mediated by reactive oxygen species and nitrogen species (Kehler and Smith, 1994; Ellah, 2010; Dong et al., 2011). High levels of LPS can provoke Kupffer cells and neutrophils to produce reactive oxygen species (ROS) in response to additional stimuli. The recruitment of phagocytic cells leads to an overabundance of ROS or impaired antioxidant status (Mier-Cabrera et al., 2011). Failure to control the accumulation of ROS adequately within metabolically active tissues will result in oxidative stress (Sordillo and Aitken, 2009).

Organisms have developed tight defensive mechanisms that strongly regulate the processing and de- 
toxification of LPS in the liver (Mølgaard et al., 2012). The balance between free radicals and antioxidants is known to be disrupted in many diseases and may be attributed to many factors, such as excess production of ROS an inability of cells to produce adequate amounts of antioxidants, and nutritional deficiencies of minerals or vitamins (Ellah, 2010). Recently, several studies have described oxidative stress as a significant factor that is responsible for impaired immune and inflammatory responses, resulting in the high susceptibility of dairy cattle to a variety of health disorders, including mastitis, retained placenta, laminitis, and poor reproductive performance, particularly during the transition period (Allison and Laven, 2000; Bernabucci et al., 2005; Wilde, 2006). The majority of LPS that enters the host under normal or pathological conditions enters through the gastrointestinal tract: the liver is the final barrier preventing gastrointestinal bacteria and their products, such as LPS, from entering the systemic circulation (Nakao et al., 1994). Due to the lack of information about the effects of experimentally induced SARA on oxidative status in dairy cattle, we hypothesized that feeding cows a high-grain diet for a long period may cause oxidative stress. Therefore, the aims of the current study were to investigate oxidative stress parameters and to highlight the molecular mechanism underlying experimentally induced SARA.

\section{MATERIALS AND METHODS}

\section{Ethical Approval}

The experiment was conducted following the guidelines of the Animal Ethics Committee, Nanjing Agricultural University, China. The Animal Ethics Committee approved the study. The sampling procedures complied with the Animal Research Institute Committee guidelines of Nanjing Agricultural University, China.

\section{Animals and Experimental Treatments}

Twelve healthy multiparous mid-lactation Holstein cows were chosen. Their average weight and milk yield at the beginning of the experiment were $455 \pm 28 \mathrm{~kg}$ and $31.59 \pm 3.2 \mathrm{~kg} / \mathrm{d}$, respectively. They were randomly arranged into 2 groups of 6 cows and assigned to receive 1 of 2 diets Table 1: either a low-grain $(\mathbf{L G}$; forage-to-concentrate 6:4) or a high-grain diet (HG; forage-to-concentrate 4:6). All cows were cannulated with permanent portal vein and hepatic vein catheters for a trial period of $18 \mathrm{wk}$. The animals were kept in individual tiestalls and were fed 3 times a day at 0400 , 1200, and 2000 h. Dry matter intake was $21.7 \pm 1.1$
Table 1. Ingredients and nutrient compositions of the treatment diets

\begin{tabular}{lcc}
\hline Item & $\begin{array}{c}\text { Low } \\
\text { grain }\end{array}$ & $\begin{array}{c}\text { High } \\
\text { grain }^{1}\end{array}$ \\
\hline $\begin{array}{l}\text { Ingredient, \% of DM } \\
\text { Corn silage }\end{array}$ & 30 & 20 \\
Alfalfa & 30 & 20 \\
Maize & 22.78 & 33.6 \\
Wheat bran & 5.15 & 15 \\
Soybean & 9.81 & 9 \\
Calcium phosphate dibasic & 0.92 & 0.53 \\
Limestone & 0 & 0.52 \\
Salt & 0.35 & 0.35 \\
Premix & 1 & 1 \\
Total & 100 & 100 \\
Nutritional composition & & \\
NE, MJ/kg & 6.32 & 6.74 \\
CP, \% & 16 & 16.2 \\
Ether extract, \% & 3.96 & 4.15 \\
NDF, \% & 37.71 & 31.92 \\
ADF, \% & 22.75 & 17.55 \\
NFC, \% & 33.43 & 40.31 \\
Starch, \% & 25.33 & 32.28 \\
Ca, \% & 0.9 & 0.8 \\
P, \% & 0.45 & 0.45 \\
\hline
\end{tabular}

${ }^{1}$ Low grain $=40 \%$ grain on a DM basis; high grain $=60 \%$ grain on a DM basis. Dibasic (Dongzhou Chemical Industry Co., Ltd, Lianyungang, Jiangsu, Nanjing, China).

${ }^{2}$ The premix contained vitamin A,1,900,000 IU/kg; vitamin D, 250,000 $\mathrm{IU} / \mathrm{kg}$; vitamin E, 3,333.33 IU/kg; niacin, $4,000 \mathrm{mg} / \mathrm{kg} ; \mathrm{Cu}, 1,200 \mathrm{mg} /$ $\mathrm{kg} ; \mathrm{Fe}, 525 \mathrm{mg} / \mathrm{kg} ; \mathrm{Zn}, 13,000 \mathrm{mg} / \mathrm{kg} ; \mathrm{Mn}, 5,500 \mathrm{mg} / \mathrm{kg} ; \mathrm{I}, 170 \mathrm{mg} / \mathrm{kg}$; $\mathrm{Co}, 50 \mathrm{mg} / \mathrm{kg}$; Se, $27 \mathrm{mg} / \mathrm{mg}$.

$\mathrm{kg} / \mathrm{d}$ per head, and the cows had free access to fresh water throughout the duration of the experiment. The cows were observed daily regarding feed ingestion, rectal temperature, and respiratory rate. The experiment was started after the animals made a full recovery, and no cows showed any clinical signs of infection during the experiment.

Blood samples were collected $4 \mathrm{~h}$ after feeding on the sampling days $(5,6$, and 7 ) of wk 18 . Blood samples were collected through the catheters in the portal and hepatic veins, using 5-mL Vacutainer tubes (supplied by Jiangsu Kangjian Medical Apparatus Co. Ltd., Nanjing, China) with sodium heparin as an anticoagulant. Plasma was isolated from the blood samples by centrifugation at $3,000 \times g$ at $4^{\circ} \mathrm{C}$ for $15 \mathrm{~min}$ and stored at $-20^{\circ} \mathrm{C}$ for LPS analysis, oxidative stress parameter measurement, and antioxidant enzyme activity assessment. All the enzymes activity and others biomarker were done with peripheral blood plasma (jugular vein plasma), whereas only LPS was measured in hepatic, portal, and peripheral (jugular vein) plasma. At wk 18 , liver tissue samples were obtained by punch biopsy (Anscitech Ltd., Wuhan, China) under local anesthesia, as previously described by Vels et al. (2009), and the tissue samples were immediately frozen in liquid nitrogen and subsequently stored at $-70^{\circ} \mathrm{C}$. 


\section{Determination of Rumen $\mathrm{pH}$ and Milk Analysis}

Rumen fluids were taken through a rumen fistula at 1-h intervals up to $12 \mathrm{~h}$ on $\mathrm{d} 5,6$, and 7 of wk 18 of the trial. The $\mathrm{pH}$ was measured immediately using a portable pH meter (HI 9125; Hanna Instruments, Woonsocket, RI). Cows were milked at 0500, 1300, and 2100 $\mathrm{h}$ and milk yield was recorded daily. A50-mL milk sample was taken to determine the milk fat and milk protein concentrations (MilkoScan FT1, Foss, Hillerød, Denmark).

\section{Determination of LPS}

Ten milliliters of rumen fluid was immediately centrifuged at $10,000 \times g$ for $45 \mathrm{~min}$ at $4^{\circ} \mathrm{C}$, filtered through a disposable $0.22-\mu \mathrm{m}$ filter, and stored in pyrogen-free glass at $-20^{\circ} \mathrm{C}$ for LPS analysis. The concentrations of LPS in the rumen fluid and plasma in the portal vein, hepatic vein and jugular vein were determined by a Chromogenic Endpoint Limulus Amebocyte Lysate Assay Kit (CE64406 \&CE80545, Chinese Horseshoe Crab Reagent Manufactory Co. Ltd., Xiamen, China), as described by Dong et al. (2013), to detect LPS concentrations in the ruminal fluid and plasma with a minimum detection limit of 0.01 endotoxin units $(\mathbf{E U}) / \mathrm{mL}$.

\section{Quantitative Real-Time PCR}

Total RNA was prepared from $50 \mathrm{mg}$ of liver tissue using Trizol (Invitrogen, Carlsbad, CA), as described by the manufacturer's protocol. The RNA quality was assessed by both agarose gel (1\%) electrophoresis and spectrometry (A260/A280) using the Eppendorf Biophotometer Plus (Eppendorf AG, Hamburg, Germany). Only samples with a ratio of A260 to A280 between 1.8 and 2.1 were used in subsequent experiments. Reverse transcription was performed using $250 \mathrm{ng} / \mu \mathrm{L}$ of RNA to synthesize cDNA with PrimeScript RT Master Mix Perfect Real Time (Takara Co., Otsu, Japan), according to the manufacturer's instructions.

Primers for genes catalase $(C A T)$, glutathione peroxidase 1 (GPX1), glutathione peroxidase 3 (GPX3), superoxide dismutase 1 (SOD1), and superoxide dismutase 2 (SOD2), superoxide dismutase 3 (SOD3), and the reference gene $\beta$-actin were obtained from previously published paper (Côrtes et al., 2012). A gene primer for pathway analysis was previously published by Gessner et al. (2013). The Nrf2-specific primer was designed using Premier primer 5.0 software (Premier Biosoft, Palo Alto, CA), and the primer sequences are provided in Table 2. Each cDNA sample was amplified using SYBR Green (Takara Co., Otsu, Japan) on the ABI 7300 Fast Real-time PCR System (Applied Bio- systems, Foster City, CA). Briefly, the reaction mixture consisted of $2 \mu \mathrm{L}$ of $\mathrm{cDNA}$ and $0.4 \mu M$ primers, 10 $\mu \mathrm{L}$ of Cyber green, $0.4 \mu \mathrm{L}$ of $\mathrm{ROX}$, and $6.8 \mathrm{~mL}$ of double-distilled water in a final volume of $20 \mu \mathrm{L}$. The quantitative real-time PCR conditions were as follows: denaturation at $95^{\circ} \mathrm{C}$ for $15 \mathrm{~s}$, followed by 40 cycles of annealing at $60^{\circ} \mathrm{C}$ for $31 \mathrm{~s}$, and extension at $72^{\circ} \mathrm{C}$. All reactions were run in triplicate. The accuracy of the quantitative real-time PCR assay was determined by the amplification efficiency, which was assessed by the dilution series measurement of a randomized cDNA mix. The amplification efficiencies of all genes are presented in Table 2 . The data were normalized to the mean of the housekeeping gene $\beta$-actin to control variability in expression levels and were analyzed using the $2^{-\Delta \Delta \mathrm{Ct}}$ method $\left[\left(\mathrm{Ct}_{\text {target gene }}-\mathrm{Ct}_{\beta \text {-actin }}\right)\right.$ treatment $\left(\mathrm{Ct}_{\text {target gene }}-\mathrm{Ct}_{\beta \text {-actin }}\right)$ control], as previously described (Livak and Schmittgen, 2001).

\section{Biochemical Analysis of Oxidative and Antioxidative Biomarkers in the Liver}

The antioxidant assays were conducted using assay kits purchased from the Nanjing Jiancheng Institute of Bioengineering (Nanjing, Jiangsu, China; Zheng et al., 2014). One gram of frozen liver tissue in $10 \mathrm{~mL}$ of homogenization buffer ( $0.9 \%$ cool physiological saline) was homogenized on ice using a Polytron-aggregate homogenizer (Polytron PT-1200E, Lucerne, Switzerland) for $30 \mathrm{~s}$ at $12,500 \mathrm{rpm}$. The homogenate was centrifuged at $3,810 \times g$ for $10 \mathrm{~min}$ at $4^{\circ} \mathrm{C}$, and the resultant supernatant ( $10 \%$ concentrations) was aliquoted; $0.9 \%$ physiological saline was used to dilute the supernatant to different concentrations, which were stored at $-20^{\circ} \mathrm{C}$ until analysis.

\section{Antioxidant Enzyme Activity}

Glutathione Peroxidase. Glutathione peroxidase $(\mathbf{G P x})$ was determined spectrophotometrically (UV3600, Daojin Corp., Kyoto, Japan) using the Nanjing Jiancheng Bioengineering Institute commercial kit at $412 \mathrm{~nm}$, as described by Hafeman et al. (1974) by the oxidizing speed of glutathione (GSH), which can be expressed by GSH reduction within a certain time. One unit of GPx activity was defined as $1 \mu \mathrm{mol} / \mathrm{L}$ of GSH oxidized to glutathione disulfide per milligram of protein per minute.

Superoxide Dismutase. The superoxide dismutase (SOD) activities of the plasma and liver samples were assayed based on the reaction system that contains xanthine; xanthine oxidase produces the superoxide anion free radical $\left(\mathrm{O}_{2}^{-}\right)$. The superoxide anion oxidizes hydroxylamine to form nitrite and was assayed spectro- 
Table 2. Primer sequences used for quantitative real-time PCR amplification of selected genes (antioxidant and survival genes) in the livers of dairy cows

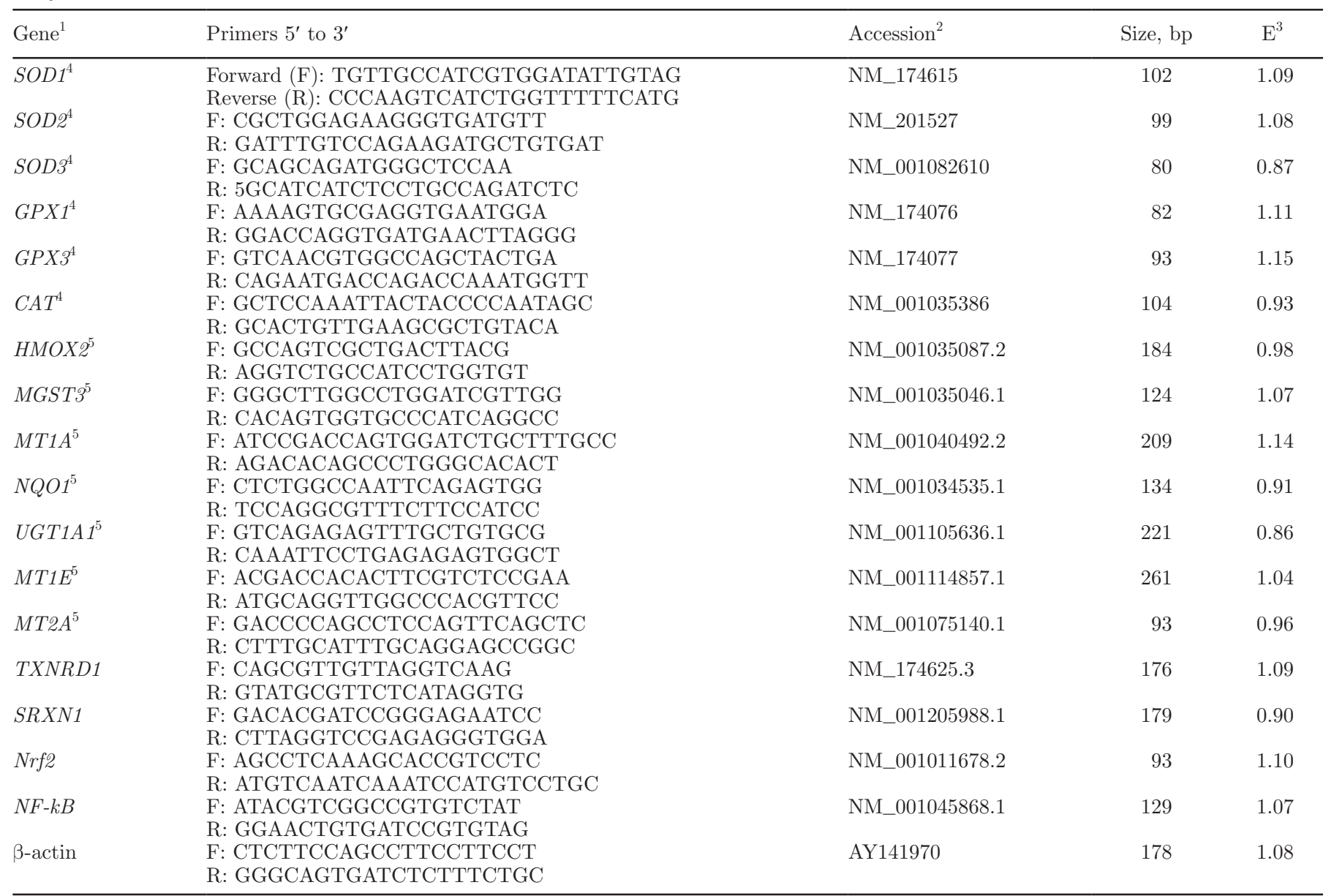

${ }^{1} S O D 1=$ superoxide dismutase $1 ; S O D 2=$ superoxide dismutase $2 ; S O D 3=$ superoxide dismutase $3 ; G P X 1=$ glutathione peroxidase $1 ; G P X 3=$ glutathione peroxidase $3 ; C A T=$ catalase $H M O X 2=$ heme oxygenase $2 ; M G S T 3=$ microsomal glutathione S-transferase $3 ; M T 1 A=$ metallothionein $1 \mathrm{~A} ; N Q O 1=\mathrm{NAD}(\mathrm{P}) \mathrm{H}$, quinone $1 ; U G T 1 A 1=\mathrm{UDP}$ glucuronosyltransferase 1 family, polypeptide A1; MT1E = metallothionein $1 \mathrm{E}$; $M T 2 A=$ metallothionein $2 \mathrm{~A} ; T X N R D 1=$ thioredoxin reductase $1 ; S R X N 1=$ sulfiredoxin $1 ; N r f 2=$ nuclear factor E2-related factor $2 ; N F-k B$ = nuclear factor kaba B.

${ }^{2}$ The reference sequence number is given for primers whose source is the National Center for Biotechnology Information (NCBI) GenBank database (http://www.ncbi.nlm.nih.gov/genbank/).

${ }^{3} \mathrm{E}=$ primer efficiency.

${ }^{4}$ Published by Côrtes et al. (2012).

${ }^{5}$ Published by Gessner et al. (2013).

photometrically (UV3600, Daojin Corp.) at $550 \mathrm{~nm}$ using Nanjing Jiancheng Bioengineering Institute commercial kits (Cat. No. A001-1 SOD). One unit of SOD is defined as the amount of sample resulting in 50\% inhibition of nitroblue tetrazolium reduction.

Catalase. Catalase (CAT) was determined spectrophotometrically (UV3600, Daojin Corp.) at 405 $\mathrm{nm}$, as described by Wang et al. (2008), using Nanjing Jiancheng Bioengineering Institute commercial kits based on the decrease in the $\mathrm{H}_{2} \mathrm{O}_{2}$ concentration in 15 s. One unit of CAT activity was defined as the amount of enzyme decomposing $1 \mathrm{~mol}$ of $\mathrm{H}_{2} \mathrm{O}_{2}$ in $1 \mathrm{~s}$. All proce- dures were performed according to the manufacturer's instructions.

\section{Lipid Peroxidation, Total Antioxidant Capacity, and Nitrous Oxide Analysis}

Malondialdehyde Measurement. Malondialdehyde (MDA) levels were measured spectrophotometrically at $532 \mathrm{~nm}$ using the thiobarbituric acid reaction method, as described by Chen et al. (2013), using commercially available kits (Nanjing Jiancheng Bioengineering Institute). Lipid peroxidation was ex- 
pressed as nanomoles of MDA per milligram of protein or nanomoles of MDA per milliliter of plasma.

Determination of Total Antioxidant Capacity. Total antioxidant capacity (T-AOC) was measured spectrophotometrically (UV3600, Daojin Corp.) using Nanjing Jiancheng Bioengineering Institute commercial kits, as described by Benzie and Strain (1996), based on the reduction of $\mathrm{Fe}^{3+}$ to $\mathrm{Fe}^{2+}$, which combines with phenanthrene and forms a colored compound detected at $520 \mathrm{~nm}$. One unit of T-AOC was defined as the extent to which optical density is increased by $0.01 \mathrm{mg}$ of protein or milliliter of plasma per minute.

Determination of Total Nitrous Oxide and Nitrous Oxide Synthase. The levels of nitrous oxide (NOS) in the liver homogenate supernatants and plasma were determined using a commercial kit (Nanjing Jiancheng Bioengineering Institute Nanjing, Cat. NO. A014-1), according to the manufacturer's protocol. Briefly, $100 \mu \mathrm{L}$ of $10 \%$ liver homogenate was incubated with $200 \mu \mathrm{L}$ of substrate buffer, $10 \mu \mathrm{L}$ of reaction accelerator, and $100 \mu \mathrm{L}$ of color developer reagent at $37^{\circ} \mathrm{C}$ for 15 min after mixing. Then, $100 \mu \mathrm{L}$ of clearing reagent and $2 \mathrm{~mL}$ of stop solution were added and mixed, and the absorbances were spectrophotometrically (UV3600, Daojin Corp.) detected at $530 \mathrm{~nm}$. To measure nitrous oxide synthase (iNOS) activity, an inhibitor was added before incubation. The principle of this assay is based on the measurement of nitric oxide produced in the sample during a timed reaction. Then, nitric oxide can produce a chromophore, which is measured at $530 \mathrm{~nm}$. The NOS activity was calculated and expressed as units per milligram of protein (liver) or units per milliliter (plasma). One unit of NOS activity was defined as the production of $1 \mathrm{nmol}$ of nitric oxide per second per milligram of tissue protein (Salter and Knowles, 1998).

\section{Western Blot Analysis}

Proteins were extracted from $100 \mathrm{mg}$ of liver tissue with RIPA buffer (Beyotime Biotechnology Co., Ltd., Shanghai, China) using a Dounce homogenizer (SigmaAldrich, St. Louis, MO) after 30 min of incubation on ice. Cell extracts were subjected to centrifugation $(12,000 \times g)$ at $4^{\circ} \mathrm{C}$ for $15 \mathrm{~min}$ to obtain the cell proteins. The supernatant was assayed for protein concentrations using the bicinchoninic acid protein assay kit (Pierce, Rockford, IL). The concentration was unified to $4 \mu \mathrm{g} / \mu \mathrm{L}$ and $10 \mu \mathrm{L}$ of protein in an SDS loading buffer, and the proteins were subjected to 10\% SDS PAGE and transferred to a nitrocellulose membrane (Millipore, Danvers, MA) at $4^{\circ} \mathrm{C}$ for $90 \mathrm{~min} ; 10 \%$ skim milk in Tris-buffered saline was used to block the membrane. Goat polyclonal antibodies against Nrf2 (Santa Cruz Biotechnology, Santa Cruz, CA, diluted by 1:200) and $\beta$-actin (Bioworld, CA; 1:10,000) were used at $4^{\circ} \mathrm{C}$ overnight, and then the membrane was washed and treated with horseradish peroxidase-conjugated rabbitanti-goat secondary antibodies. Immunoreactive proteins were detected by chemiluminescence using ECL reagent (Super Signal West Pico Trial Kit, Pierce) and subsequently autoradiographed. Quantitation of the results was performed by Bio-Rad Gel Doc 2000 Systems (Bio-Rad, Hercules, CA) and analyzed with Bio-Rad TDS Quantity One software (Bio-Rad). The relative quantities of proteins were determined by a densitometer and expressed as absorbance units.

\section{Statistical Analysis}

All statistical analyses were performed with SAS software (SAS version 9.2, SAS Institute Inc., Cary, NC); the mixed procedure of SAS was used to analyze $\mathrm{pH}$ and the milk production data with a repeated measures design. The 3 last consecutive days of wk 18 for the $\mathrm{pH}$ data were averaged within a cow by hours before analysis, whereas milk production data were averaged within a cow by a week during the whole experimental period before analysis. For the $\mathrm{pH}$ data, the effects of diet and time were considered as fixed factors, and the time within treatments and cows was considered as repeated measurements. For the milk data, the weeks within treatments and cows were considered as repeated measures. The effects of diet and weeks were considered as fixed factors. The effects of cows were considered random for both $\mathrm{pH}$ and milk data. Compound symmetry was used as the type of covariance. The residuals for each variable were used to assess normality. Differences between groups for the genes expression, enzymes activity, and LPS were analyzed with the 2 -sample $t$-test. The correlations were analyzed by Pearson's model in SAS. Differences were considered significant when $P$ $<0.05$. The data were presented as mean \pm standard error of the mean. Graphs were made using Graph Pad Prism version 5.01 (Graph Pad Software, La Jolla, CA).

\section{RESULTS}

\section{Rumen $\mathrm{pH}$ and LPS Content in Rumen Fluid and Blood Plasma}

Long-term feeding with a $60 \%$ grain diet resulted in a decrease in rumen $\mathrm{pH}$ from 6.055 to $<5.8$ for $270 \mathrm{~min} / \mathrm{d}$ $(P=0.001$; Figure 1$)$. Lipopolysaccharide concentrations in the rumen fluid, hepatic vein plasma, portal vein plasma, and jugular vein plasma were higher in the cows fed HG than in the cows fed LG $(P=0.01, P=$ $0.001, P=0.01$, and $P=0.001$; Table 3 ). 
Table 3. Lipopolysaccharide concentrations in the plasma and rumen of dairy cows fed low- (LG) and highgrain $(\mathrm{HG}) \operatorname{diets}^{1}$

\begin{tabular}{|c|c|c|c|c|}
\hline \multirow[b]{2}{*}{ Item } & \multicolumn{2}{|c|}{ Treatment } & \multirow[b]{2}{*}{ SEM } & \multirow[b]{2}{*}{$P$-value } \\
\hline & LG & HG & & \\
\hline Rumen LPS, $\mathrm{EU}^{2} / \mathrm{mL} \times 10^{3}$ & 47.17 & 79.04 & 7.94 & $<0.001$ \\
\hline Portal vein plasma LPS, EU/mL & 0.78 & 1.42 & 0.09 & $<0.001$ \\
\hline Hepatic vein plasma LPS, EU/mL & 0.52 & 0.93 & 0.06 & $<0.01$ \\
\hline Jugular vein plasma LPS, EU/mL & 0.47 & 0.86 & 0.08 & $<0.001$ \\
\hline
\end{tabular}

${ }^{1}$ The LPS concentrations were compared between HG and LG using Student's $t$-test, $P \leq 0.05$ was considered significant.

${ }^{2} \mathrm{EU}=$ endotoxin unit.

\section{Milk Yield and Composition}

The results showed that the milk yield, percentage of milk fat, and the milk fat yield were decreased $(P=$ $0.03, P=0.01$, and $P=0.01$, respectively) in cows fed HG compared with cows fed LG. However, the percentage of milk protein increased remarkably in the group fed HG ( $P=0$ 0.05; Table 4$)$. Milk yields were initially higher in the HG diet than the LG diet for $7 \mathrm{wk}$, then start to decrease gradually in HG compared with that in LG (Figure 2).

\section{Expression Levels of Target Genes}

As shown in Figure $3 \mathrm{~A}$, the results revealed a decrease in GPX1 $(P=0.001)$ and $C A T(P=0.04)$ in the HG; furthermore, SOD2 $(P=0.07), S O D 3$, and $G P X 3$ levels tended to decrease in cows fed a high-grain diet. The $S O D 1$ was increased $(P=0.001)$ in cows fed HG compared with those fed LG.

\section{Nrf2-Related Genes and the Relative Expression of NF-kB}

Target gene mRNA abundance is reported in Figure 3. We observed increase in NF- $k B$ mRNA expression $(P$ $=0.001)$ in the liver tissue harvested from HG, whereas Nrf2 mRNA expression $(P=0.004)$ was lower in the HG than in LG. Furthermore, Nrf2 target genes, such as NQO1, MT1E, MGST3, MT1A, and UGT1A1, were downregulated in the HG compared with the LG cows $(P=0.001, P=0.011, P=0.002, P=0.001$, and $P=$ 0.023, respectively). However, other Nrf2 target genes, such as TXNRD1, HMOX2, SRXN1, and MT2A, were not affected by HG.

\section{Enzyme Activity, MDA, T-AOC, and Nitrous Oxide Synthase Activity}

The antioxidant and lipid peroxide profiles in the livers and plasma of the dairy cows subjected to the
2 treatments ( $\mathrm{HG}$ and $\mathrm{LG}$ ) are presented in Figure 4 and Figure 5. The SOD activity was increased ( $P$ $=0$. 001) by HG (Figure 4A), but HG significantly reduced GPx and CAT activity $(P=0.048$ and $P$ $=0.028$, respectively; Figure 4B, C). Consistent with liver and plasma enzyme activity, our results revealed a significant increase $(P=0.018)$ in SOD activity and a significant decrease in GPx and CAT activity $(P=$ 0.002 and $P=0.003)$ in HG cows compared with LG cows (Figure 5A, B, C).

The lipid peroxides in the livers and plasma are shown in Figure 4D and Figure 5D. We observed increase in MDA production $(P=0.041$ and $P=0.029)$ in $\mathrm{HG}$ cows, whereas T-AOC was prominently decreased $(P$ $=0.039$ and $P=0.043$, respectively) in both the liver and the plasma of the HG group (Figure 4E and Figure $5 \mathrm{E})$. Total NOS and iNOS activity in the liver and

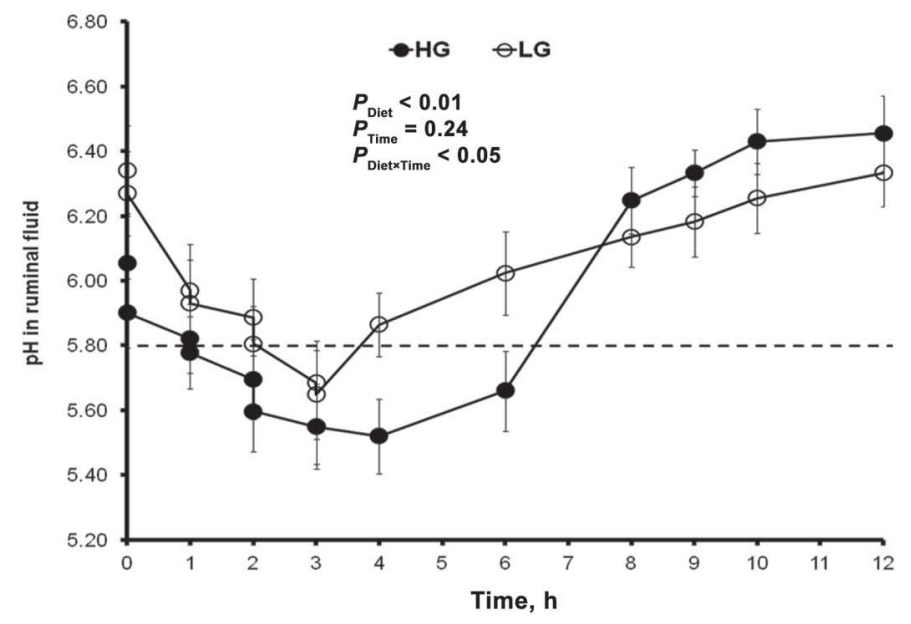

Figure 1. Comparison of $\mathrm{pH}$ values in the ruminal fluid between the low- (LG) and high-grain (HG) groups. Ruminal fluid samples were collected at times ranging from 0 to $12 \mathrm{~h}$ for 3 consecutive days during wk 18. Data were analyzed by the mixed procedure of SAS software (SAS version 9.2, SAS Institute Inc., Cary, NC) and expressed as the mean \pm SEM. Significant differences were observed across all sampling times $(P<0.05)$. 
Table 4. Milk yield and milk composition during experimental period in cows fed a high-grain (HG) versus low-grain (LG) diet

\begin{tabular}{|c|c|c|c|c|c|c|}
\hline \multirow[b]{2}{*}{ Item $^{1}$} & \multicolumn{2}{|c|}{ Treatment } & \multirow[b]{2}{*}{ SEM } & \multicolumn{3}{|c|}{ Effect, $P$-value } \\
\hline & LG & $\mathrm{HG}$ & & Diet & Week & Week $\times$ diet \\
\hline Milk yield, $\mathrm{kg} / \mathrm{d}$ & 28.02 & 25.95 & 0.25 & $<0.03$ & $<0.07$ & $<0.01$ \\
\hline Milk fat, \% & 3.40 & 2.99 & 0.05 & $<0.01$ & $<0.09$ & $<0.06$ \\
\hline Fat yield, $\mathrm{kg}$ & 0.95 & 0.86 & 0.02 & $<0.01$ & 0.21 & $<0.04$ \\
\hline Protein yield, \% & 3.06 & 3.38 & 0.04 & $<0.05$ & 0.18 & $<0.05$ \\
\hline Protein, kg & 0.85 & 0.86 & 0.2 & 0.88 & 0.29 & 0.52 \\
\hline
\end{tabular}

${ }^{1}$ The milk yield and milk compositions were analyzed by mixed model of SAS with repeated measures, $P \leq$ 0.05 was considered significant.

plasma tended to increase in response to HG (Figure $4 \mathrm{~F}, \mathrm{G}$ and Figure 5F, G, respectively).

The correlation analysis showed that the plasma LPS concentration was positively correlated with hepatic MDA, plasma MDA $(\mathrm{r}=0.62 ; P=0.05, \mathrm{r}=0.81 ; P$ $=0.01)$, and liver SOD activity $(\mathrm{r}=0.73, P=0.01)$ in cows fed the HG diet (Figure 6A, C, D), whereas the plasma LPS concentration was negatively correlated with hepatic and plasma GPx activity $(\mathrm{r}=-0.64, P=$ $0.05, \mathrm{r}=-0.77 ; P=0.01$ ) in the HG (Figure 6B, E). No correlation was observed between plasma LPS and plasma SOD activity $(\mathrm{r}=0.20, P=0.54)$ in cows fed HG diet (Figure 6F).

\section{Nrf2 Protein Expression}

As shown in Figure 7, the expression levels of Nrf2 protein were decreased $(P=0.006)$ in the livers of cows fed HG versus those fed LG.

\section{DISCUSSION}

Oxidative stress has been implicated in numerous disease processes in ruminants. A limited number of conditions in ruminant medicine have been investigated with regard to the effects of oxidative stress. To evaluate the role of endogenous LPS in oxidative stress during the feeding of a high-grain diet and to study the underlying mechanism of this phenomenon, we first confirmed the presence of SARA by measuring the concentration of LPS in peripheral plasma and the $\mathrm{pH}$ of the rumen at several time points. Second, we ensured that the parameters of oxidative stress were triggered in the livers and blood plasma of cows fed a high-grain diet.

Ruminal $\mathrm{pH}$ thresholds $<5.8$ are generally used to diagnose SARA (Ghorbani et al., 2002). The pH values of the ruminal fluid are shown in Figure 1. The dynamic curve of the $\mathrm{pH}$ levels in the $\mathrm{HG}$ group was lower than the $\mathrm{pH}$ curve in the LG group. The curve showed that the rumen $\mathrm{pH}$ values remained under 5.8 in the HG group for $270 \mathrm{~min} / \mathrm{d}$, which indicated SARA was induced successfully (Steele et al., 2011). Overall, the $\mathrm{pH}$ values were different between the 2 groups $(P$ $=0.05)$.

Systemic clearance and detoxification of LPS occurs in the Kupffer cells in the liver (Vels et al., 2009). Excessive production of cytokines in the liver can damage hepatocytes (Schattenberg et al., 2011).The impairment of hepatocytes during HG feeding may contribute to the decreased percentage of LPS clearance in the liver. Consistent with previous reports in feedlot and dairy cows, our results revealed higher concentrations of LPS $(P=0.001)$ in the peripheral plasma $(0.86 \mathrm{EU} / \mathrm{mL})$ of cows fed HG than in the peripheral plasma of cows fed LG $(0.47 \mathrm{EU} / \mathrm{mL})$, whereas rumen LPS increased from $47,166.70$ to $79,042.11 \mathrm{EU} / \mathrm{mL}$ compared with the LG group after $4 \mathrm{~h}$ (Khafipour et al., 2009; Dong et al., 2014). The same studies reported increased levels of acute phase protein in grain-based SARA (Khafipour et al., 2009). Furthermore, Dong et al. (2013) reported significant upregulation of Toll-like receptor 4 and IL-

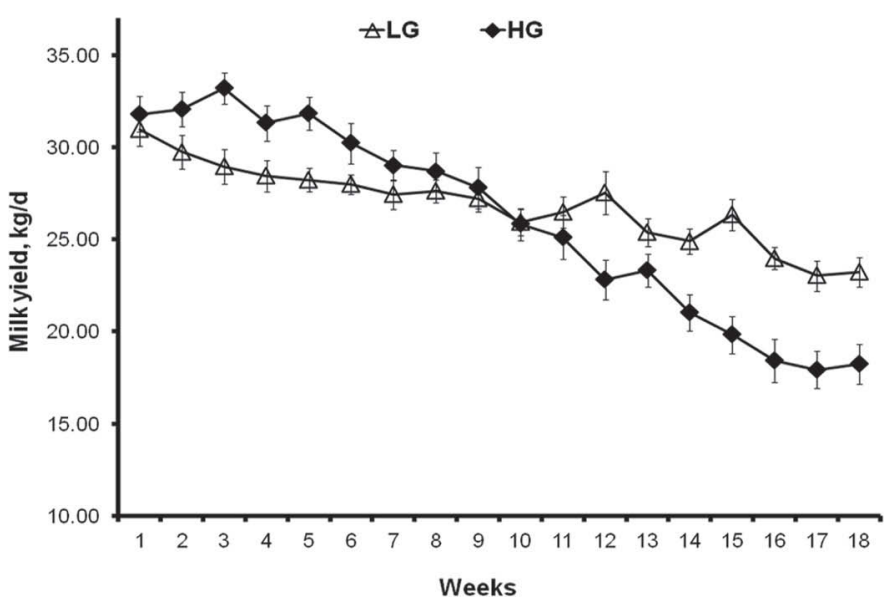

Figure 2. Effect of long-term feeding of a high-grain diet on milk yields. Milk data were collected from the 2 groups of dairy cows fed either a high- (HG) diet or low-grain (LG) diet for 18 wk. Data were analyzed by the mixed procedure of SAS software (SAS version 9.2, SAS Institute Inc., Cary, NC), and expressed as the mean \pm SEM. 
1b mRNA expression in the livers of goats fed high concentrates in addition to significant upregulation of mRNA expression of acute phase proteins, including hepatic serum amyloid $\mathrm{A}, \mathrm{C}$ reactive protein, and haptoglobin mRNA, accompanied by marked increases in serum amyloid $\mathrm{A}$ and haptoglobin in the plasma of goats fed high concentrates.

We observed high concentrations of LPS in the portal and hepatic veins of cows fed HG compared with cows fed LG. Taking the rumen and portal vein LPS concentrations into consideration, our findings indicated that HG induced the translocation of LPS from the digestive tract into the blood stream and likely initiated an innate immune response. Moreover, our results revealed lower levels of milk yield $(\mathrm{kg} / \mathrm{d})$, milk fat $(\%)$, and milk fat yield $(\mathrm{kg} / \mathrm{d})$ in cows fed HG, which has been previously reported by Dong et al. (2011). Free circulating LPS may depress the activity of key enzymes in milk component synthesis, such as acetyl-CoA carboxylase, lipoprotein lipase, and fatty acid synthase.

Our results confirmed the presence of oxidative stress in cows fed HG. Enhanced SOD activity represents the response of the organism to superoxide radicals $\left(\mathrm{O}_{2}^{\cdot-}\right)$ generated during experimentally induced SARA (Hassan et al., 2005). Moreover, Guo et al. (2013), noted lower concentrations of plasma T-AOC and higher concentrations of plasma MDA in cows fed a diet containing $20 \%$ finely ground wheat, leading to increased
A

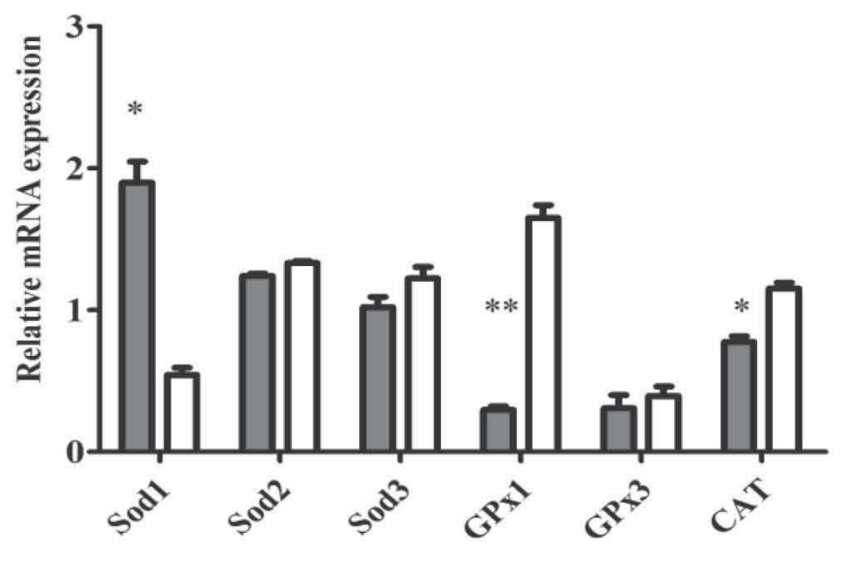

C

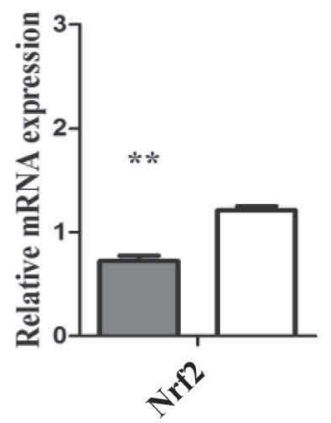

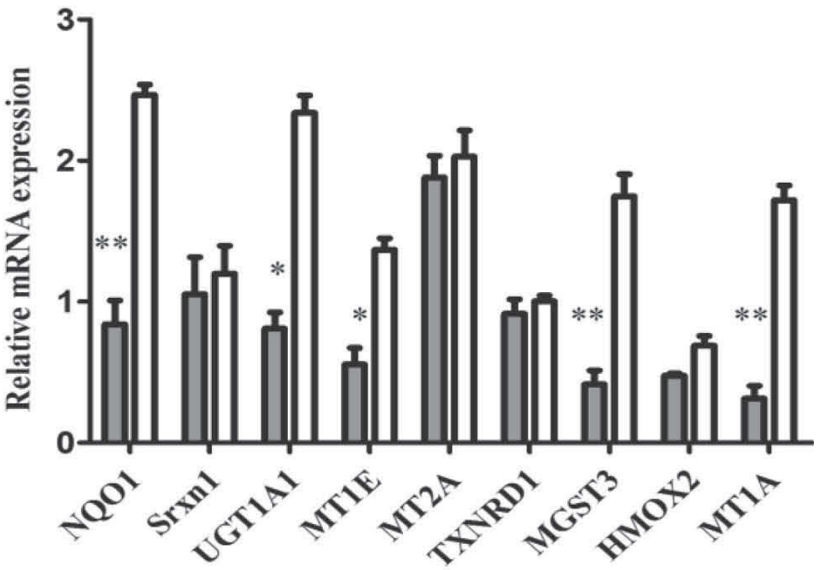

D

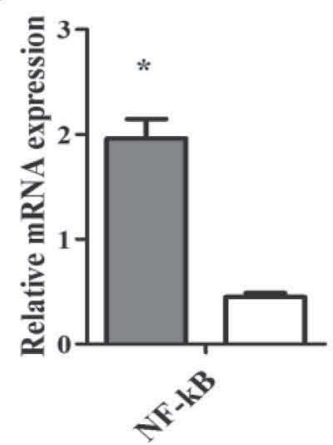

Figure 3. Effect of endogenous LPS on relative mRNA expression in the livers of cows fed the high- (HG) versus low-grain diets (LG). Gene

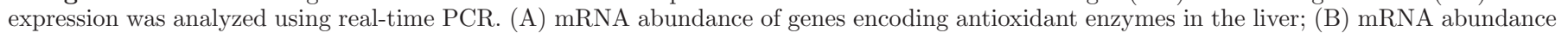

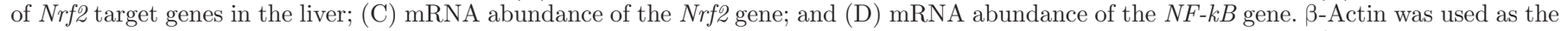

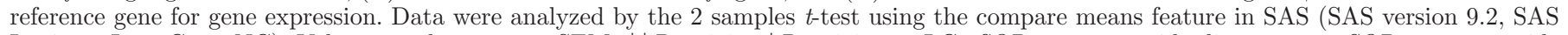
Institute Inc., Cary, NC). Values are the mean \pm SEM. ${ }^{*} * P<0.01,{ }^{*} P<0.05$ vs. LG. $S O D 1=$ superoxide dismutase $1 ; S O D 2=$ superoxide

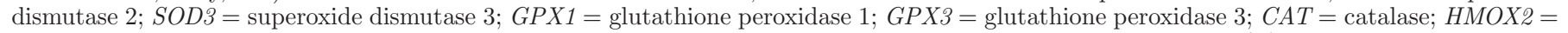
heme oxygenase $2 ; M G S T 3=$ microsomal glutathione S-transferase $3 ; M T 1 A=$ metallothionein $1 \mathrm{~A} ;$ NQO1 $=\mathrm{NAD}(\mathrm{P}) \mathrm{H}$ dehydrogenase, quinone

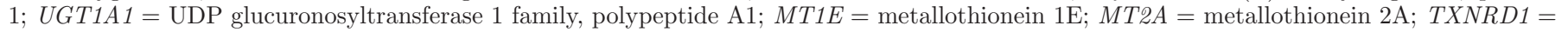
thioredoxin reductase $1 ; S R X N 1=$ sulfiredoxin $1 ; N r f 2=$ nuclear factor E2-related factor $2 ; N F-k B=$ nuclear factor kaba B. 
A

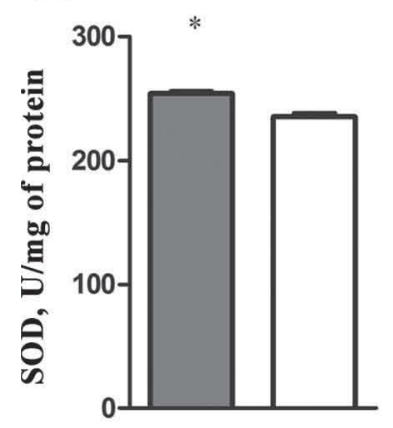

B

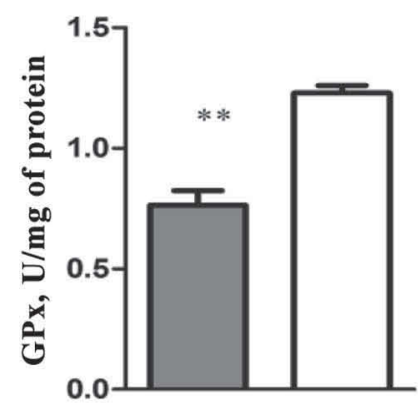

C

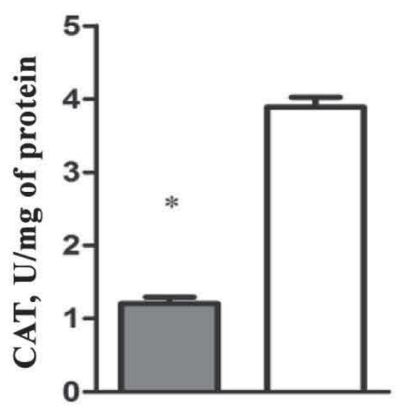

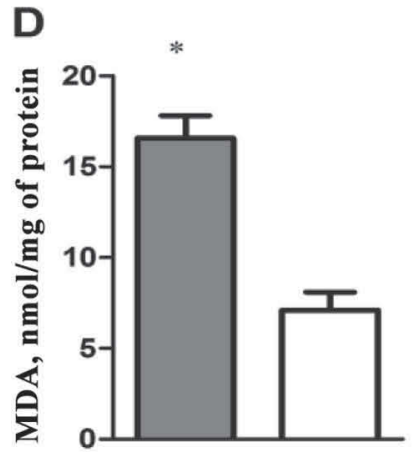
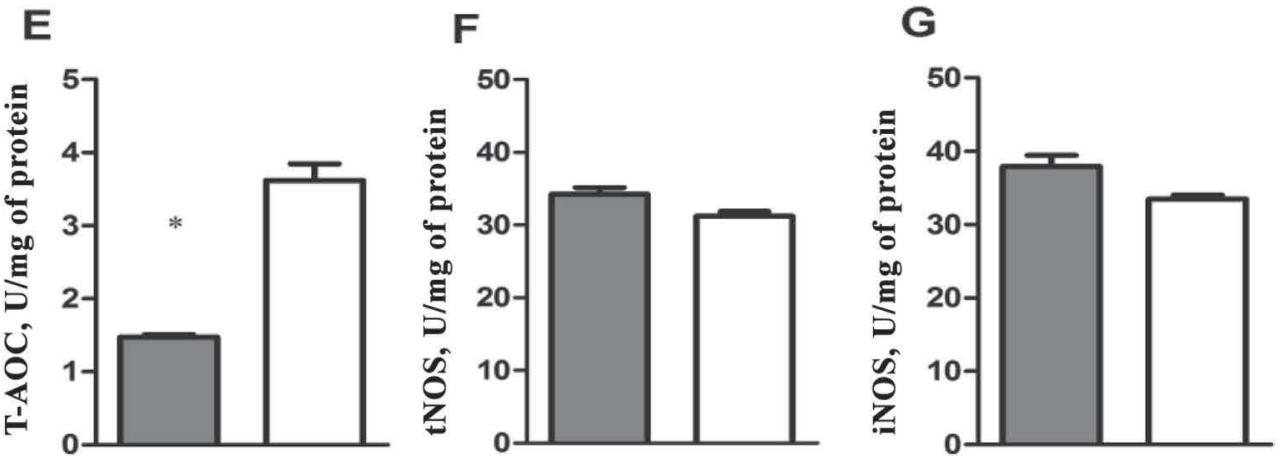

Figure 4. Effect of endogenous LPS on antioxidant enzyme activity, lipid peroxidation, total antioxidant capacity, and NOS activity in the liver of cows fed the high- (HG) versus low-grain diets (LG). (A) Total SOD activity; (B) GPx activity; (C) catalase activity; (D) MDA; (E) T-AOC; (F) tNOS; and (G) iNOS activity. The results are expressed as the mean \pm SEM. Data were analyzed by the 2 samples $t$-test using the compare means feature in SAS (SAS version 9.2, SAS Institute Inc., Cary, NC). ${ }^{*} P<0.05,{ }^{*} P<0.01$ vs. LG. SOD $=$ superoxide dismutase; $\mathrm{GPx}=$ glutathione peroxidase; $\mathrm{CAT}=$ catalase $\mathrm{MDA}=$ malondialdehyde; $\mathrm{T}-\mathrm{AOC}=$ total antioxidant capacity; tNOS $=$ total nitrous oxide synthase; iNOS $=$ induced total nitrous oxide synthase.

SOD and glutathione peroxidase activity compared with $0 \%$ finely ground wheat group. Although SOD activity was increased in both the plasma and the livers of cows fed a high-grain diet, GPx and CAT activity was significantly decreased. This has previously been observed in liver tissues under disease conditions, such as diabetes, as a result of important adaptive responses to increased peroxidative stress (Ananthan et al., 2004). In other studies, similar responses to $\mathrm{H}_{2} \mathrm{O}_{2}$ treatment over time were observed for both plasma GPx and CAT, which are enzymes that degrade $\mathrm{H}_{2} \mathrm{O}_{2}$. According to Kehler and Smith, (1994) the increased production of $\mathrm{H}_{2} \mathrm{O}_{2}$ is due to a rise in SOD activity, and protection from reactive oxygen substances would be provided only by a simultaneous increase in CAT and GPx activities in the presence of glutathione. On the other hand, Watson et al. (1999) studied the activities of conjugating and antioxidant enzymes following endotoxin exposure in male Sprague Dawley rats and concluded that total SOD activity and CAT and GPx activity were decreased at different time points following endotoxin administration. Our results indicate that the constitutive presence of SOD and the lack of upregulated GPx and CAT may lead to an elevated capacity to produce $\mathrm{O}_{2}$ and $\mathrm{H}_{2} \mathrm{O}_{2}$ (Spolarics, 1996). However, as $\mathrm{H}_{2} \mathrm{O}_{2}$ has low redox potential, we suggest that its derivatives, such as the hydroxyl radical $(\bullet \mathrm{OH})$, may play central roles in mitochondrial dysfunction. According to Almeida et al. (2006), who studied isolated rat liver mitochondria exposed to $\mathrm{Fe}^{2+}$-citrate complexes, $\bullet \mathrm{OH}$ is derived from $\mathrm{H}_{2} \mathrm{O}_{2}$ in the presence of ferrous iron $\left(\mathrm{Fe}^{2+}\right)$, which is reported to be responsible for mitochondrial damage.

We observed reduced levels of T-AOC and increased concentrations of MDA. This suggests that cows fed HG are more susceptible to oxidative stress than cows fed LG. The results are supported by Hou et al. (2008), who demonstrated that cows fed a high-grain diet had higher serum MDA levels and lower serum T-AOC levels than cows fed a low-grain diet (Guo et al., 2013). Additionally, Guo et al. (2013) stated that oxidative stress is encountered due to host endogenous antioxi- 
dant defenses. The increase in MDA and the decrease in T-AOC indicate that the pro-oxidants overwhelmed the antioxidants and exerted lipid peroxidation (Peavy and Fairchild, 1986), which can be explained by the downregulation of antioxidant genes, likely impairing the capacity of the liver to cope with the increased levels of ROS and to prevent oxidative stress.

At the genetic level, our study revealed high expression of SOD1 but nonsignificant decreases in the levels of other SOD isoforms, which is consistent with SOD activity; this may be because SOD1 is the most abundant isoform (Johnson and Giulivi, 2005). Moreover, Dobashi et al. (1997) showed decreased CAT, GPx, and SOD2 mRNA and increased SOD1 mRNA in rat C6 glial cells due to nitrous oxide, which is known to be elevated by LPS. However, Cao et al. (2006) reported the downregulation of $S O D$ in sheep livers following intravenous injection of LPS in a dose-dependent manner. This discrepancy exists in other studies, which have demonstrated the induction of liver tissue SOD2 due to LPS challenge in rats after $24 \mathrm{~h}$ (Xie et al., 2006). These results indicate that $S O D$ gene expression varies in the liver following LPS challenge, taken together with the result of correlation analysis between the plasma LPS versus the antioxidant enzymes activity in the plasma and the liver of cows fed HG, supports our hypothesis that endogenous LPS may play a role in the regulation of stress genes in experimentally induced SARA. Our results were consistent with Cani et al. (2008), who reported appositive correlation of metabolic endotoxemia (translocated LPS) with inflammation and oxidative stress in the mice fed a high-fat diet, same as a highgrain diet but with the gram-negative-to-gram-positive bacteria ratio increased in the high-fat diet; accordingly, the LPS concentration increased and entered the blood stream. The upregulation of SOD1 may indicate the persistence of oxidative stress due to long-term exposure to superoxide tension (Brown et al., 2004). The mRNA abundance of CAT was downregulated, which may be due to the inhibitory effect of NF-kB because its promoter is bound by NF-kB (p50) in unstimulated cells (Zhou et al., 2001; Schreiber et al., 2006).

The Nf-E2 related factor-2 (Nrf2), which is known as a redox-sensitive transcription factor, is a basic leucine
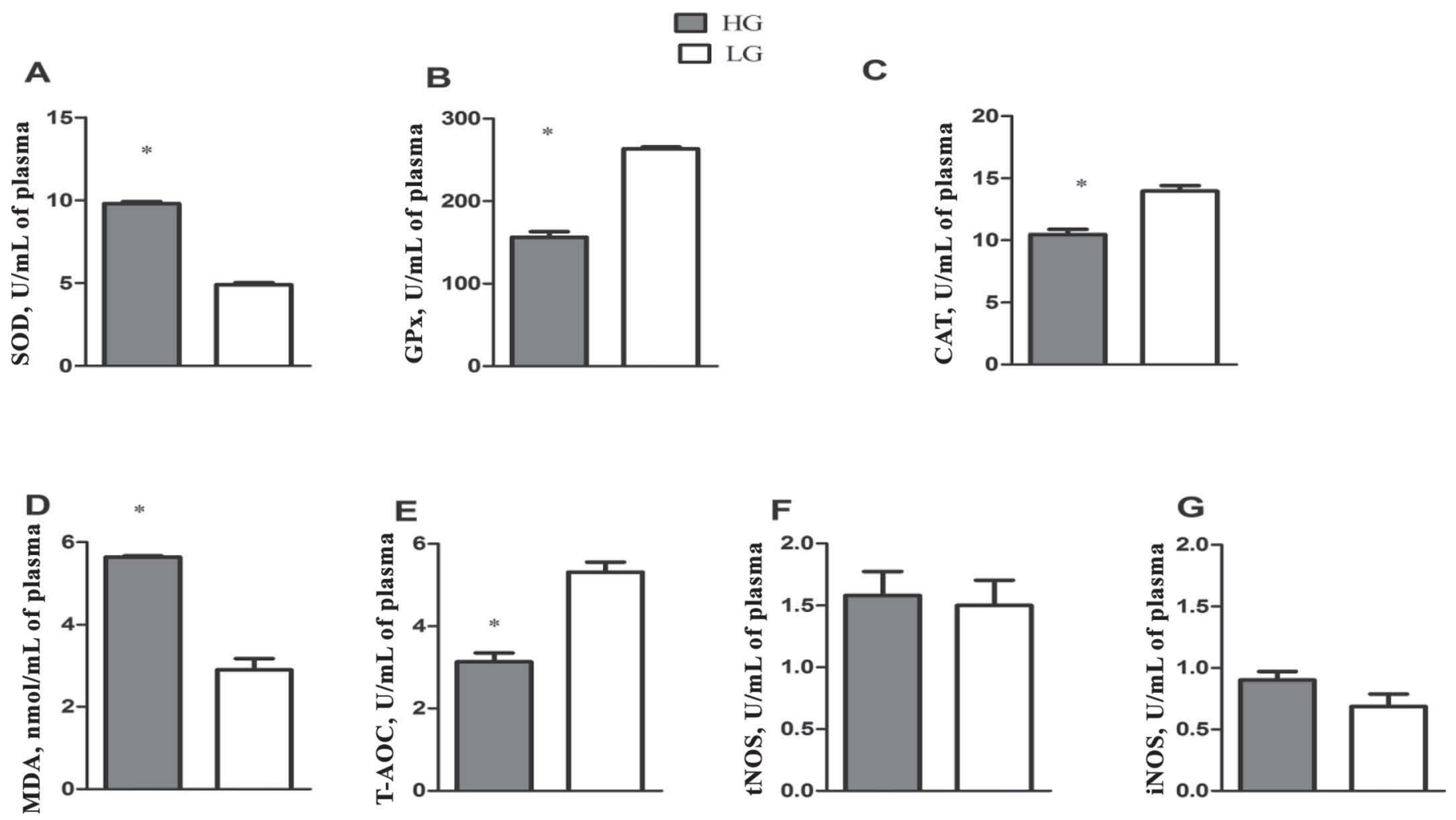

Figure 5. Effect of endogenous LPS on antioxidant enzyme activity, lipid peroxidation, total antioxidant capacity, and NOS activity in the plasma of cows fed a high- (HG) compared with a low-grain diet (LG). (A) Total SOD activity; (B) GPx activity; (C) catalase activity; (D) MDA; (E) T-AOC; (F) tNOS; and (G) iNOS activity. All enzyme activity and biomarkers were evaluated spectrophotometrically, and the results are expressed as the mean \pm SEM. Data were analyzed by the 2 samples $t$-test using the compare means feature in SAS (SAS version 9.2, SAS Institute Inc., Cary, NC). ${ }^{*} P<0.05$ vs. LG. SOD $=$ superoxide dismutase; $\mathrm{GPx}=$ glutathione peroxidase; CAT $=$ catalase; MDA $=$ malondialdehyde; $\mathrm{T}-\mathrm{AOC}=$ total antioxidant capacity; $\mathrm{tNOS}=$ total nitrous oxide synthase; iNOS $=$ induced total nitrous oxide synthase. 

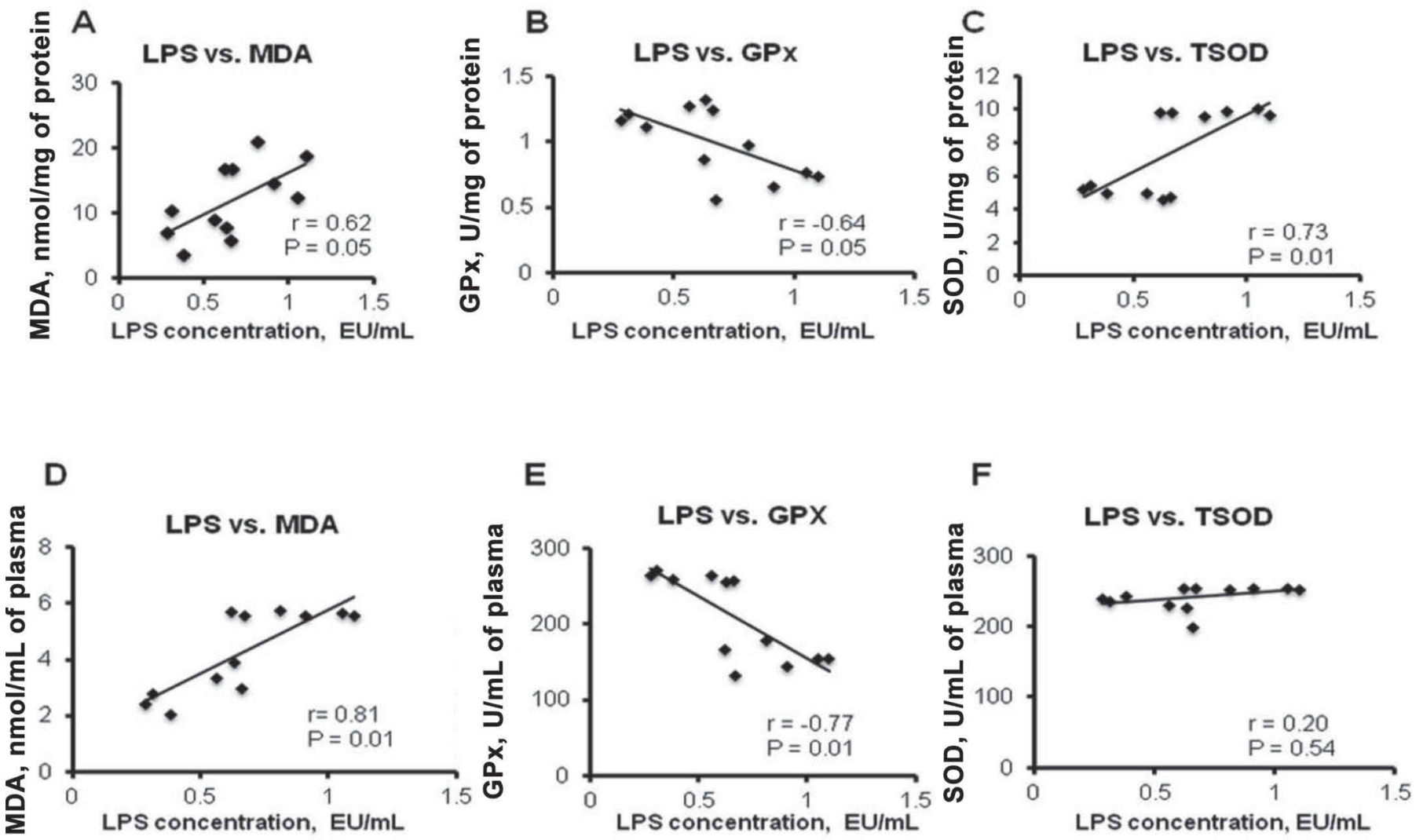

Figure 6. Pearson correlation between plasma LPS concentration and hepatic antioxidant enzymes activity or plasma antioxidant enzymes activity in the cows fed a high-grain (HG) diet. (A) Lipopolysaccharide in the plasma versus malondialdehyde (MDA) in the liver; (B) LPS in the plasma versus glutathione peroxidase (GPx) in the liver; (C) LPS in the plasma versus total superoxide dismutase (TSOD) in the liver; (D) LPS in the plasma versus MDA in the plasma; (E) LPS in the plasma versus GPx in the plasma; and (F) LPS in the plasma versus TSOD in the plasma. Data were analyzed using Pearson's model of SAS (SAS version 9.2, SAS Institute Inc., Cary, NC). Values are mean \pm SEM, $\mathrm{n}=$ 6/group. The results indicate a significant correlation through the $P$-value at the 0.05 or 0.01 levels.

zipper transcription factor that binds and activates the antioxidant response element in the promoters of several antioxidant and cytoprotective genes in response to oxidative stress (Gessner et al., 2013). We found that HG treatment decreased the expression levels of Nrf2 protein in the livers versus LG. This result is consistent with the quantitative real-time PCR results, which showed a decrease in Nrf2 mRNA levels in response to HG. This can be explained by chronic elevation of $\mathrm{H}_{2} \mathrm{O}_{2}$ due to downregulation of CAT and GPx at both the mRNA and the enzyme levels (Tan et al., 2011). Furthermore, decreased Nrf2 protein and Nrf2 mRNA may be attributed to other pathways, such as NF-kB, which was significantly upregulated by HG treatment. Thimmulappa et al. (2006) reported greater activation of NF-kB in Nrf2-deficient mice embryonic fibroblasts, leading them to conclude that Nrf2 regulation of cellular glutathione and other antioxidants is vital for optimal NF-kB activation in response to LPS. This result indicates that the $N F-\kappa B$ signaling pathway may mediate oxidative stress-induced hepatic injury and that Nrf2 is downregulated due to crosstalk with $N F-\kappa B$ in a high-grain diet (Li et al., 2013). However, among the survival genes encoded by Nrf2, 5 genes were downregulated, including NQO1, UGT1A1, MT1E, MGST3 (Xie et al., 2015), and MT1A, whereas other survival genes, including TXNRD1, HMOX2, SRXN1, and MT2A, were not affected by the diet. It is known that mild oxidative stress induces Nrf2, a transcription factor implicated in the activation of genes encoding antioxidant enzymes, and that moderate amounts of ROS trigger an inflammatory response through the activation of NF- $\kappa$ B. However, severe oxidative stress induces perturbation of the mitochondrial permeability transition pore and the disruption of electron transfer, leading to apoptosis or necrosis (Gloire et al., 2006; Halliwell and Gutteridge, 2011).

\section{CONCLUSIONS}

According to our results, long-term feeding with HG led to a compromise in the antioxidant defense of the 


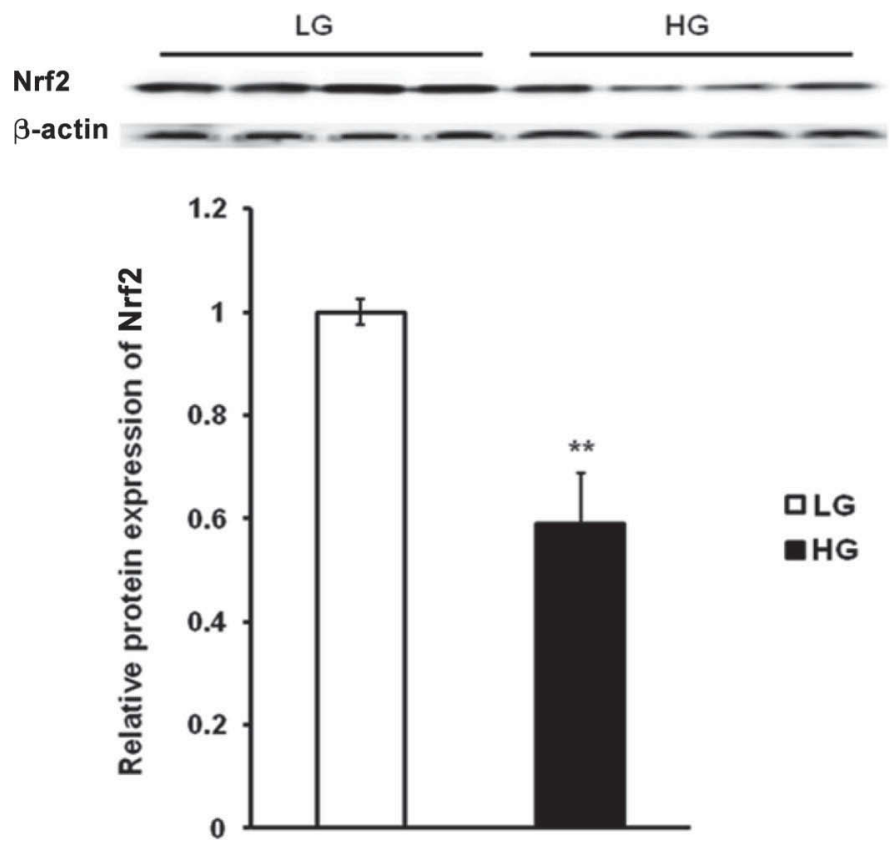

Figure 7. Effect of endogenous LPS on the relative expression of nuclear factor E2-related factor 2 (Nrf2) protein in the cows livers when they were fed high- (HG) compared with low-grain diets (LG). $\beta$-Actin was used as the reference protein; Nrf2 protein was significantly lower versus low concentrate. Data were analyzed by the 2 samples $t$-test using the compare means feature in SAS (SAS version 9.2, SAS Institute Inc., Cary, NC).Values are mean $\pm \mathrm{SEM} ;{ }^{* *} P<0.01$ vs. LG.

body in dairy cows and resulted in oxidative damage due the suppression of cellular antioxidant defense capacity, suggesting some relationships between translocated LPS and impairment of the Nrf2-dependent antioxidant response.

\section{ACKNOWLEDGMENTS}

The National Basic Research Program of China (Beijing; no. 2011CB100802), National Natural Science Foundation of China (Beijing; no. 31172371), and the Priority Academic Program Development of Jiangsu Higher Education Institutions (Nanjing, China, PAPD) funded this work. The authors are grateful to James Hadley from School of Languages, Trinity College, Dublin, Ireland, for helping in the revision of the manuscript.

\section{REFERENCES}

Allison, R. D., and R. A. Laven. 2000. Effect of vitamin E supplementation on the health and fertility of dairy cows: A review. Vet. Rec. 147:703-708.

Almeida, A. M., C. R. Bertoncini, J. Borecký, N. C. Souza-Pinto, and A. E. Vercesi. 2006. Mitochondrial DNA damage associated with lipid peroxidation of the mitochondrial membrane induced by Fe2+-citrate. An. Acad. Bras. Cienc. 78:505-514.
Ananthan, R., M. Latha, K. Ramkumar, L. Pari, C. Baskar, and V. Narmatha Bai. 2004. Modulatory effects of gymnema montanum leaf extract on alloxan-induced oxidative stress in wistar rats. Nutrition 20:280-285.

Benzie, I. F., and J. Strain. 1996. The ferric reducing ability of plasma (FRAP) as a measure of "antioxidant power": The FRAP assay. Anal. Biochem. 239:70-76.

Bernabucci, U., B. Ronchi, N. Lacetera, and A. Nardone. 2005. Influence of body condition score on relationships between metabolic status and oxidative stress in periparturient dairy cows. J. Dairy Sci. 88:2017-2026.

Brown, N. M., A. S. Torres, P. E. Doan, and T. V. O'Halloran. 2004. Oxygen and the copper chaperone CCS regulate posttranslational activation of $\mathrm{Cu}, \mathrm{Zn}$ superoxide dismutase. Proc. Natl. Acad. Sci. USA 101:5518-5523.

Cani, P. D., R. Bibiloni, C. Knauf, A. Waget, A. M. Neyrinck, N. M. Delzenne, and R. Burcelin. 2008. Changes in gut microbiota control metabolic endotoxemia-induced inflammation in high-fat diet-induced obesity and diabetes in mice. Diabetes 57:1470-1481.

Cao, H., L. C. Kabaroff, Q. You, A. Rodriguez, H. J. Boermans, and N. A. Karrow. 2006. Characterization of ovine hepatic gene expression profiles in response to Escherichia coli lipopolysaccharide using a bovine cDNA microarray. BMC Vet. Res. 2:34.

Chen, X., F. Ren, J. Hesketh, X. Shi, J. Li, F. Gan, Z. Hu, and K. Huang. 2013. Interaction of porcine circovirus type 2 replication with intracellular redox status in vitro. Redox Rep. 18:186-192.

Côrtes, C., M. F. Palin, N. Gagnon, C. Benchaar, P. Lacasse, and H. V. Petit. 2012. Mammary gene expression and activity of antioxidant enzymes and concentration of the mammalian lignan enterolactone in milk and plasma of dairy cows fed flax lignans and infused with flax oil in the abomasum. Br. J. Nutr. 108:1390-1398.

Dobashi, K., K. Pahan, A. Chahal, and I. Singh. 1997. Modulation of endogenous antioxidant enzymes by nitric oxide in rat C6 glial cells. J. Neurochem. 68:1896-1903.

Dong, G., S. Liu, Y. Wu, C. Lei, J. Zhou, and S. Zhang. 2011. Dietinduced bacterial immunogens in the gastrointestinal tract of dairy cows: Impacts on immunity and metabolism. Acta Vet. Scand. 53:48.

Dong, G., M. Qiu, C. Ao, J. Zhou, X. Wang, Z. Zhang, and Y. Yang. 2014. Feeding a high-concentrate corn straw diet induced epigenetic alterations in the mammary tissue of dairy cows. PLoS ONE 9:e107659.

Dong, H., S. Wang, Y. Jia, Y. Ni, Y. Zhang, S. Zhuang, X. Shen, and R. Zhao. 2013. Long-term effects of subacute ruminal acidosis (SARA) on milk quality and hepatic gene expression in lactating goats fed a high-concentrate Diet. PLoS ONE 8:e82850.

Ellah, M. R. A. 2010. Involvement of free radicals in animal diseases. Comp. Clin. Pathol. 19:615-619.

Emmanuel, D. G., S. M. Dunn, and B. N. Ametaj. 2008. Feeding high proportions of barley grain stimulates an inflammatory response in dairy cows. J. Dairy Sci. 91:606-614.

Gessner, D. K., G. Schlegel, J. Keller, F. Schwarz, R. Ringseis, and K. Eder. 2013. Expression of target genes of nuclear factor E2-related factor 2 in the liver of dairy cows in the transition period and at different stages of lactation. J. Dairy Sci. 96:1038-1043.

Ghorbani, G. R., D. Morgavi, K. Beauchemin, and J. Leedle. 2002. Effects of bacterial direct-fed microbials on ruminal fermentation, blood variables, and the microbial populations of feedlot cattle. J. Anim. Sci. 80:1977-1985.

Gloire, G., S. Legrand-Poels, and J. Piette. 2006. NF- $\kappa$ B activation by reactive oxygen species: Fifteen years later. Biochem. Pharmacol. 72:1493-1505.

Gozho, G. N., J. Plaizier, D. Krause, A. Kennedy, and K. Wittenberg. 2005. Subacute ruminal acidosis induces ruminal lipopolysaccharide endotoxin release and triggers an inflammatory response. J. Dairy Sci. 88:1399-1403.

Guo, Y., X. Xu, Y. Zou, Z. Yang, S. Li, and Z. Cao. 2013. Changes in feed intake, nutrient digestion, plasma metabolites, and oxidative stress parameters in dairy cows with subacute ruminal acidosis and its regulation with pelleted beet pulp. J. Anim. Sci. Biotechnol. $4: 31$ 
Hafeman, D. G., R. Sunde, and W. Hoekstra. 1974. Effect of dietary selenium on erythrocyte and liver glutathione peroxidase in the rat. J. Nutr. 104:580-587.

Halliwell, B., and J. Gutteridge. 2011. Free Radicals in Biology and Medicine. Oxford University Press, London, UK.

Hassan, L., P. Bueno, I. Ferrón-Celma, J. Ramia, D. Garrote, K. Muffak, A. Garcı-Navarro, A. Mansilla, J. Villar, and J. Ferron. 2005. Time course of antioxidant enzyme activities in liver transplant recipients. Transplant. Proc. 37:3932-3935.

Hou, Z. G., Z. Y. Wang, T. J. Chai, Y. D. Jia, Q. L. Gong, J. Ma, and Y. t. Wang. 2008. Effects of forage to concentrate ratio on homeostasis of rumen and oxidative stress in cows. Acta Vet. Zootech. Sin. 39:455.

Jiang, J., S. Bahrami, G. Leichtfried, H. Redl, W. Ohlinger, and G. Schlag. 1995. Kinetics of endotoxin and tumor necrosis factor appearance in portal and systemic circulation after hemorrhagic shock in rats. Ann. Surg. 221:100-106.

Johnson, F., and C. Giulivi. 2005. Superoxide dismutases and their impact upon human health. Mol. Aspects Med. 26:340-352.

Kallapura, G., N. Pumford, X. Hernandez-Velasco, B. Hargisand, and G. Tellez. 2014. Mechanisms involved in lipopolysaccharide derived ROS and RNS oxidative stress and septic shock. J. Microbiol. Res. Rev 2:6-11.

Kehler, J., and C. Smith. 1994. Free radical in biology: Sources, reactivities and roles in the etiology of human disease. Pages 25-62 in Natural Antioxidants in Human Heaith and Disease. Academic Press, San Diego, CA.

Khafipour, E., D. Krause, and J. Plaizier. 2009. A grain-based subacute ruminal acidosis challenge causes translocation of lipopolysaccharide and triggers inflammation. J. Dairy Sci. 92:1060-1070.

Kleen, J. L., G. Hooijer, J. Rehage, and J. Noordhuizen. 2003. Subacute ruminal acidosis (SARA): A review. J. Vet. Med. A Physiol. Pathol. Clin. Med. 50:406-414.

Li, Y., Y. Huang, Y. Piao, K. Nagaoka, G. Watanabe, K. Taya, and C. Li. 2013. Protective effects of nuclear factor erythroid 2-related factor 2 on whole body heat stress-induced oxidative damage in the mouse testis. Reprod. Biol. Endocrinol. 11:23.

Livak, K. J., and T. D. Schmittgen. 2001. Analysis of relative gene expression data using real-time quantitative PCR and the 2 sup$\Delta \Delta \mathrm{CT} /$ sup Method. Methods 25:402-408.

Mier-Cabrera, J., L. Jiménez Zamudio, E. García Latorre, O. Cruz Orozco, and C. Hernández Guerrero. 2011. Quantitative and qualitative peritoneal immune profiles, $\mathrm{T}$ cell apoptosis and oxidative stress associated characteristics in women with minimal and mild endometriosis. BJOG 118:6-16.

Mølgaard, L., B. M. Damgaard, V. Bjerre-Harpøth, and M. S. Herskin. 2012. Effects of percutaneous needle liver biopsy on dairy cow behaviour. Res. Vet. Sci. 93:1248-1254.

Nakao, A., S. Taki, M. Yasui, Y. Kimura, T. Nonami, A. Harada, and H. Takagi. 1994. The fate of intravenously injected endotoxin in normal rats and in rats with liver failure. Hepatology 19:12511256

Peavy, D. L., and E. J. Fairchild. 1986. Evidence for lipid peroxidation in endotoxin-poisoned mice. Infect. Immun. 52:613-616.

Salter, M., and R. G. Knowles. 1998. Assay of NOS activity by the measurement of conversion of oxyhemoglobin to methemoglobin by NO. Methods Mol. Biol. 100:61-65.
Schattenberg, J. M., M. Schuchmann, and P. R. Galle. 2011. Cell death and hepatocarcinogenesis: Dysregulation of apoptosis signaling pathways. J. Gastroenterol. Hepatol. 26(Suppl 1):213-219.

Schreiber, J., R. G. Jenner, H. L. Murray, G. K. Gerber, D. K. Gifford, and R. A. Young. 2006. Coordinated binding of NF-kappaB family members in the response of human cells to lipopolysaccharide. Proc. Natl. Acad. Sci. USA 103:5899-5904.

Sordillo, L. M., and S. L. Aitken. 2009. Impact of oxidative stress on the health and immune function of dairy cattle. Vet. Immunol. Immunopathol. 128:104-109.

Spolarics, Z. 1996. Endotoxin stimulates gene expression of ROS-eliminating pathways in rat hepatic endothelial and Kupffer cells. Am. J. Physiol. 270:G660-G666.

Steele, M. A., J. Croom, M. Kahler, O. AlZahal, S. E. Hook, K. Plaizier, and B. W. McBride. 2011. Bovine rumen epithelium undergoes rapid structural adaptations during grain-induced subacute ruminal acidosis. Am. J. Physiol. Regul. Integr. Comp. Physiol 300:R1515-R1523.

Tan, Y., T. Ichikawa, J. Li, Q. Si, H. Yang, X. Chen, C. S. Goldblatt, C. J. Meyer, X. Li, and L. Cai. 2011. Diabetic downregulation of Nrf2 activity via ERK contributes to oxidative stress-induced insulin resistance in cardiac cells in vitro and in vivo. Diabetes 60:625-633.

Thimmulappa, R. K., H. Lee, T. Rangasamy, S. P. Reddy, M. Yamamoto, T. W. Kensler, and S. Biswal. 2006. Nrf2 is a critical regulator of the innate immune response and survival during experimental sepsis. J. Clin. Invest. 116:984-995.

Vels, L., C. M. Røntved, M. Bjerring, and K. L. Ingvartsen. 2009. Cytokine and acute phase protein gene expression in repeated liver biopsies of dairy cows with a lipopolysaccharide-induced mastitis. J. Dairy Sci. 92:922-934.

Wang, D., L. j. Wang, F. x. Zhu, J. y. Zhu, X. D. Chen, L. Zou, and M. Saito. 2008. In vitro and in vivo studies on the antioxidant activities of the aqueous extracts of Douchi (a traditional Chinese salt-fermented soybean food). Food Chem. 107:1421-1428.

Watson, A. M., G. Warren, G. Howard, S. I. Shedlofsky, and R. A. Blouin. 1999. Activities of conjugating and antioxidant enzymes following endotoxin exposure. J. Biochem. Mol. Toxicol. 13:63-69.

Wilde, D. 2006. Influence of macro and micro minerals in the periparturient period on fertility in dairy cattle. Anim. Reprod. Sci. 96:240-249.

Xie, W., N. Shao, X. Ma, B. Ling, Y. Wei, Q. Ding, G. Yang, N. Liu, H. Wang, and K. Chen. 2006. Bacterial endotoxin lipopolysaccharide induces up-regulation of glyceraldehyde-3-phosphate dehydrogenase in rat liver and lungs. Life Sci. 79:1820-1827.

Xie, Z., X. Jiang, P. Ye, Y. Zhang, Y. Ni, S. Zhuang, and X. Shen. 2015. Relationship between liver and low rumen $\mathrm{pH}$ in goat. Genet. Mol. Res. 14:209-221.

Zheng, W., Y. Hou, and W. Yao. 2014. Lactulose increases equol production and improves liver antioxidant status in barrows treated with daidzein. PLoS ONE 9:e93163.

Zhou, L. Z., A. P. Johnson, and T. A. Rando. 2001. NF kappa B and AP-1 mediate transcriptional responses to oxidative stress in skeletal muscle cells. Free Radic. Biol. Med. 31:1405-1416. 